\title{
ILOKUSI YANG MEMBERIKAN EFEK HUMOR KEPADA PEMBACA DALAM MANGA AZUMANGA DAIOH
}

\author{
Febryan Ariefandi \\ ariefandi@gmail.com \\ Universitas Gadjah Mada
}

\begin{abstract}
The purpose of this study is to describe the form and meaning of illocutionary acts which create humor effect in the manga entitled Azumanga Daioh Volume 1 by Azuma Kiyohiko. The data source of this study is the casts' speeches which have potential to be an illocutionary acts. Data were collected and analyzed based on theory of Searle illocutionary acts. Data were also analyzed using theory of Grice cooperative principle to find a maxim of cooperative principle's violation. The type of this study is qualitative description with pragmatic approach. The result of this study showed that illocutionary acts within Azumanga Daioh Volume 1 categorized at five illocutionary forms, consisted of assertive "admitting", "claiming", and "speculating", directive "requirement" and "prohibition", expressive "criticisms", comissive "offering", and declarative "deciding". Those illocutionary acts also violated maxim of cooperative principles that are maxim of quantity, maxim of quantity, maxim of relevance, and maxim of manner. Illocutionary acts are also acts as a support to create humor within speeches.
\end{abstract}

Keywords : Speech Acts, Illocutionary Acts, Cooperative Principle, Violation, Humor

Setiap orang pasti memiliki selera humor. Ada yang senang memendamnya karena malu, ada juga yang berani mengekspresikannya. Secara umum, humor adalah segala rangsangan mental yang secara spontan menimbulkan senyum dan tawa para penikmatnya. Humor juga dapat didefinisikan sebagai cerita yang menggelitik dan membuat tertawa pendengar atau pembaca yang mengerti maksud humor tersebut. Dalam Ensiklopedia Indonesia (1982), seperti yang dinyatakan oleh Setiawan (1990), Humor itu kualitas untuk menghimbau rasa geli atau lucu, karena keganjilannya atau ketidakpantasannya yang menggelikan; paduan antara rasa kelucuan yang halus di dalam diri manusia dan kesadaran hidup yang iba dengan sikap simpatik."

Salah satu media penyampaian humor adalah media cetak yaitu komik. Menurut Kamus Besar Bahasa Indonesia Daring (2012), komik adalah cerita bergambar (di 
majalah, surat kabar, atau berbentuk buku) yg umumnya mudah dicerna dan lucu. Komik adalah cerita yang bertekanan pada gerak dan tindakan yang ditampilkan lewat urutan gambar yang dibuat secara khas dengan paduan kata-kata. Komik dapat diterbitkan dalam berbagai bentuk, mulai dari strip dalam koran, dimuat dalam majalah, hingga berbentuk buku tersendiri.

Manga adalah istilah untuk menyebutkan komik dalam bahasa Jepang. Di luar Jepang, kata tersebut digunakan khusus untuk menyebutkan komik buatan Jepang. Manga menyajikan cerita dengan khayalan-khayalan yang penyajiannya dikaitkan dengan realita keseharian. Hal tersebut seperti kegiatan sekolah, situasi belajar, keadaan kota, dan lain sebagainnya. Mangaka adalah sebutan untuk para pembuat manga di Jepang. Dalam setiap karyanya, para mangaka selalu berusaha menghasilkan manga yang dapat menggugah perasaan para pembacanya.

Salah satu jenis manga yang disukai oleh penggemar komik Jepang adalah manga humor. Kelucuan dalam manga humor terletak pada sikap masing-masing tokoh yang terkesan lucu, aneh, dan unik, yang dituangkan dalam bentuk gambar maupun tuturan tokoh dalam berkomunikasi. Salah satu keunikan yang dimiliki dari manga humor yaitu bentuk-bentuk tuturan yang melanggar prinsip kerjasama, yang selanjutnya pelanggaran tersebut dapat memberikan efek humor. Pengarang manga selaku penutur sengaja menuliskan tuturan-tuturan yang melanggar prinsip kerja sama untuk menciptakan efek lucu ketika dibaca oleh pembaca manga sebagai mitra tutur.

Maksim merupakan prinsip yang harus ditaati oleh peserta tutur dalam berinteraksi, baik secara tekstual maupun interpersonal dalam upaya melancarkan jalannya proses komunikasi. Grice (1975) mengemukakan bahwa komunikasi yang baik dapat terjadi apabila antara penutur dan mitra tutur patuh pada Prinsip Kerja Sama (Cooperative Principle) komunikasi yang dibagi menjadi empat Maksim Percakapan (Conversational Maxim) yaitu, Maksim Kuantitas (Maxim of Quantity), Maksim Kualitas (Maxim of Quality), Maksim Relevansi (Maxim of Relevance), dan Maksim Cara (Maxim of Manner).

John L. Austin (1962:5) mengemukakan bahwa bahasa tidak hanya sekedar untuk menyampaikan informasi, akan tetapi dalam bahasa juga terdapat tindak atau aktifitas yang disebut Tindak Tutur (Speech Acts). Tindak Tutur merupakan satuan dalam pragmatik, yaitu studi yang mempelajari tentang makna tuturan. Studi ini 
Febryan Ariefandi, Ilokusi yang Memberikan Efek Humor kepada Pembaca dalam Manga Azumanga Daioh

mempelajari makna bahasa menurut konteks atau situasi tertentu dengan mengkaji apa yang dimaksudkan orang dan bagaimana konteks itu berpengaruh terhadap apa yang dikatakan, karena studi ini mengaitkan makna dengan siapakah mitra tuturnya, di mana, kapan, dan dalam keadaaan apa. Austin membagi Tindak Tutur menjadi tiga jenis, yaitu Tindak Tutur Lokusi (tindak mengatakan sesuatu), Tindak Tutur Ilokusi (tindak melakukan sesuatu), dan Tindak Tutur Perlokusi (tindak membujuk seseorang). Lalu John R. Searle (1969) membagi lagi tindak tutur ilokusi menjadi lima Daya Ilokusi yaitu Asertif (Assertive), Direktif (Directive), Komisif (Comissive), Ekspresif (Expressive), dan Deklaratif (Declarative).

Berkaitan dengan humor, Tindak Tutur Ilokusi sangat berperan penting sebgai penunjang efek humor tersebut. Tokoh dalam humor menggunakan tuturan untuk berinteraksi dengan tokoh lainnya. Tokoh di dalam humor bertutur juga melakukan sesuatu, dan mengharapkan reaksi dari orang yang mendengarkan pembicaraannya agar melakukan tindakan-tindakan yang disebutkan dalam tuturannya itu.

Salah satu contoh manga humor yang terkenal di Jepang adalah Azumanga Daioh karya Azuma Kiyohiko. Manga ini diterbitkan pertama kali dalam majalah manga bernama Dengeki Daioh pada tahun 1999 dan berakhir hingga tahun 2002. Azumanga Daioh adalah manga humor yang mengisahkan tentang kehidupan sekelompok gadis-gadis SMA dan gurunya yang memiliki sifat aneh, unik, dan cenderung "ajaib". Manga ini memiliki delapan tokoh utama yang terdiri dari enam gadis SMA yaitu Chiyo, Sasaki, Oosaka, Yomi, Tomo, Kagura, serta tiga guru mereka yaitu Yukari sensei, Kurosawa sensei, dan Kimura sensei.

Kelucuan dalam manga Azumanga Daioh ini terletak pada tuturan yang digunakan para tokoh dalam berkomunikasi. Hal ini yang dijadikan sebagai dasar oleh penulis untuk meneliti Tindak tutur Ilokusi yang terdapat dalam tuturan-tuturan tokoh manga yang memiliki fungsi sebagai penunjang terjadinya humor.

\section{METODE}

Penulis menggunakan penelitian yang bersifat kualitatif dan sebagai cara penyajiannya penulis menggunakan metode deskriptif guna menganalisis tuturan yang mengandung tindak tutur ilokusi sebagai penunjang terjadinya efek humor dalam manga Azumanga Daioh Volume 1. 
Langkah-langkah yang penulis lakukan untuk mengumpulkan data ialah 1.) Penulis membaca dan mencermati tuturan-tuturan tokoh pada percakapan yang berhubungan dengan tema yang dikaji dalam manga Azumanga Daioh volume 1 versi bahasa Jepang dan menggunakan manga versi bahasa Inggris yang digunakan sebagai referensi, 2) Penulis mengartikan tuturan-tuturan tokoh ke dalam bahasa Indonesia dan menggunakan manga Azumanga Daioh volume 1 versi bahasa Inggris sebagai referensinya, 3.) Penulis mencari dan memilih dialog yang tuturannya diasumsikan mengandung Tindak Tutur Ilokusi dan melanggar maksim pada Prinsip Kerja Sama. Setelah ditemukan, penulis akan menulis kembali dialog tersebut yang kemudian tuturannya akan dijadikan data dalam proses selanjutnya yaitu proses analisis, 4.) Mendata seluruh tuturan tokoh-tokoh yang mengandung Tindak Tutur Ilokusi dan melanggar Prinsip Kerja Sama lalu mengelompokkan data dengan mengkategorikannya berdasarkan jenis daya Ilokusinya yang terkandung dalam setiap tuturan. Daya ilokusi tersebut antara lain : asertif (assertive), direktif (directive), ekspresif (expressive), komisif (comissive), dan deklaratif (declarative).

Kemudian, penulis melakukan analisis data dengan cara berikut ; 1) Memahami dan menganalis konteks percakapan yang mengandung Tindak Tutur Ilokusi dan mengandung proses terjadinya pelanggaran Prinsip Kerja Sama dalam tuturan tokohtokoh, 2) Menentukan maksud sebenarnya dari ujaran yang diucapkan oleh petutur sesuai dengan situasi ujaran, 3.) Menganalisis dan mengidentifikasikan tuturan dengan teori Tindak Tutur Ilokusi Searle, 4.) Menganalisis faktor penyebab ditentukannya tuturan tersebut sebagai tuturan yang ber Tindak Tutur Ilokusi sesuai dengan daya ilokusinya masing-masing, 5.) Menganalisis faktor terbentuknya humor dari tuturan Tindak Tutur Ilokusi tersebut, 6.) Menganalisis dan mengidentifikasikan tuturan dengan teori prinsip kerja sama Grice, 7.) Memaparkan hasil penelitian secara deskriptif.

\section{HASIL DAN PEMBAHASAN}

Dalam manga Azumanga Daioh Volume 1 ditemukan 13 dialog para tokoh dengan 13 tuturan yang mengandung Tindak Tutur Ilokusi dan mengandung kesan lucu (humor). Setelah tuturan dikumpulkan dan dianalisis, ditemukan lima jenis Tindak Tutur Ilokusi sebagai berikut, yaitu: 1) Asertif (Assertive), 2) Direktif 
Febryan Ariefandi, Ilokusi yang Memberikan Efek Humor kepada Pembaca dalam Manga Azumanga Daioh

(Directive), 3) Komisif (Commissive), 4) Ekspresif (Expressive), dan 5.) Deklaratif (Declarative). Tuturan tersebut terdiri dari empat tuturan kategori direktif (memerintah dan melarang), lima tuturan kategori asertif (mengakui, menyatakan, dan berspekulasi), dua tuturan ekspresif (mengkritik), satu tuturan komisif (menawarkan), dan satu tuturan deklaratif (memutuskan).

\section{Humor Dalam Bentuk Direktif}

\subsection{Humor Direktif "Meminta"}

Di bawah ini adalah gambar dialog yang tuturan tokohnya masuk dalam kategori Ilokusi Direktif “meminta”. Dialog ini terdapat pada manga Azumanga Daioh Volume 1 halaman 24.

\section{Gambar 1.1}

Dialog 1 (車で Go!)
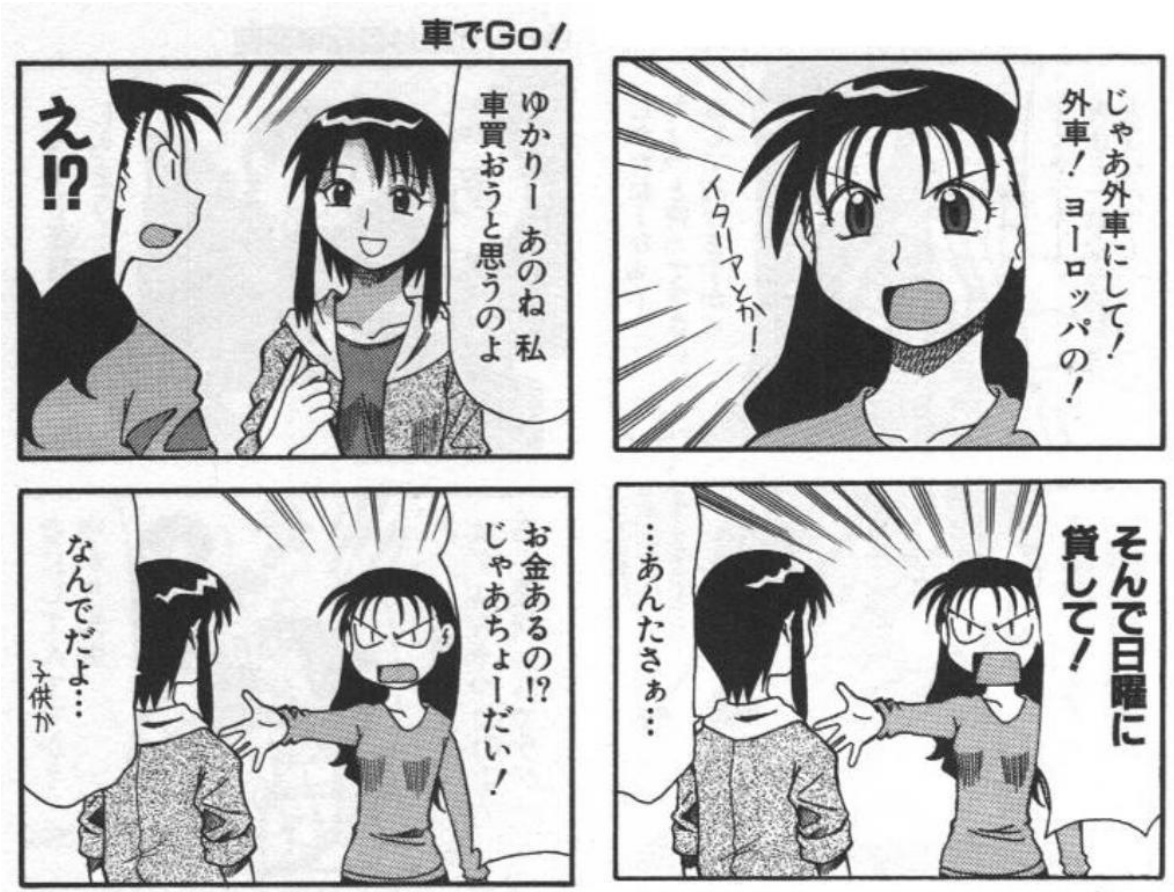

\section{Konteks Dialog 1}

Partisipan dalam dialog 1 terjadi antara Kurosawa Minamo dan Tanizaki Yukari. Mereka adalah teman sekaligus rekan guru di sekolah yang sama. Percakapan tersebut terjadi ketika Nyamo (nama panggilan Kurosawa Minamo) berkunjung ke rumah Yukari. Nyamo mengutarakan keinginannya untuk membeli sebuah mobil kepada Yukari. Mendengar keinginan Nyamo tersebut, Yukari memberikan tanggapan 
tak terduga dengan menyuruh Nyamo untuk memberikan uang kepada dirinya. Ia juga menyuruh Nyamo untuk membeli mobil import khususnya mobil Eropa, dan meminjamkan kepada dirinya setiap hari Minggu.

Tindak Tutur Ilokusi yang terdapat pada dialog 1 adalah Direktif "memerintah". Tuturan Yukari sebagai penutur mengandung maksud agar Nyamo selaku mitra tutur melakukan sesuatu sebagaimana diinginkan oleh si penutur dengan kadar tuntutan yang lebih tinggi dari meminta atau memohon. Hal ini dapat dibuktikan pada tuturan dialog 1 nomor 2 yaitu え! ? お金あるの！?じやあちょーだい! (e !? okane aru no !? jyaa cho -dai !) yang berarti "Hah !? Kamu punya uang !? Sini kasih aku !". Kata perintah yang digunakan Yukari dalam tuturan tersebut adalah "choudai” (ちょ 一だい). Selain itu, pada tuturan nomor 4 yaitu じやあ外車にして! 外車! ヨーロ ッパの!イタリアとか！そんで日曜に貸して! (jyaa gaisha ni shite! gaisha! yoroppa no ! itaria toka! sonde nichiyou ni kashite! ) yang berarti "kalau gitu beli mobil import ! mobil import ! Mobil Eropa ! atau Italia! Lalu pinjamkan padaku di hari Minggu!", kata perintah yang digunakan oleh Yukari adalah -te kudasai (ーてく ださい). Hal itu dapat dibuktikan pada pemakaian verbaーして dan 貸して diakhir kalimat yang merupakan penyederhanaan dari kataーしてください dan 貸してくだ さい. Menurut Iori (2000: 46) ungkapan menyatakan perintah dalam bahasa Jepang (命令を表す表現) salah satunya ditandai dengan penggunaan kata てください/ー んでください/ーちょうだい(-te kudasai/-ndekuasai/-choudai).

Di dalam tuturan dialog 1 nomor 2 Yukari memerintah Nyamo untuk memberikan uangnya yang akan digunakan untuk membeli sebuah mobil. Selain itu, Yukari juga memerintah Nyamo dengan semaunya sendiri untuk membeli mobil import, dan meminjamkan kepadanya setiap hari Minggu. Makna ilokusi dari tuturan tersebut adalah penyampaian perasaan iri Yukari kepada Nyamo. Sebagai sahabat dekat dan sesama rekan guru di sekolah, Yukari yang selalu memakai sepeda ketika berangkat ke sekolah merasa iri dengan Nyamo yang memiliki uang untuk membeli sebuah mobil. Hal ini ditunjang dengan sifatnya yang egois dan selalu iri atas kebahagiaan yang dimiliki oleh orang lain. Dalam sebuah percakapan, tuturan Yukari yang terdapat pada dialog 1 nomor 2 dan 4 tersebut dapat dikategorikan sebagai 
Febryan Ariefandi, Ilokusi yang Memberikan Efek Humor kepada Pembaca dalam Manga Azumanga Daioh

tuturan yang tidak wajar karena ia seenaknya sendiri meminta dan memaksakan kehendaknya kepada Nyamo. Tuturan tidak wajar inilah yang menimbulkan efek humor. Sebagai manga humor, mangaka selaku penutur dalam manga ini sengaja membuat tuturan Yukari tidak wajar agar percakapan tersebut menjadi lucu dan pembaca merasa terhibur. Apabila tuturan Yukari dibuat menjadi tuturan biasa, misalnya “そうか。外車どう?イタリアのが一番いいと思うよ。” yang berarti "Oh gitu. Gimana kalau mobil import? Menurutku mobil Itali paling bagus, lho", tuturan Direktif yang masuk dalam kategori "menyarankan" tersebut akan terkesan datar dan tidak akan menimbulkan kesan lucu bagi pembaca.

Selain itu, dikarenakan tuturan Yukari pada dialog 1 nomor 2 dan 4 tidak memiliki keterkaitan dengan tuturan Nyamo, tuturan Yukari juga telah melanggar Maksim Relevansi pada Prinsip Kerja Sama. Hal ini dapat dibuktikan ketika Nyamo mengutarakan niatnya untuk membeli sebuah mobil dengan tuturan ゆかり〜 あの ね。私車買おうと思うのよ。(Yukari ano ne. watashi kuruma kaou to omou no yo.) "Yukari Gini. Aku berencana mau beli mobil nih.". Tanggapan yang dibutuhkan Nyamo kepada Yukari adalah opininya mengenai keinginan Nyamo untuk membeli sebuah mobil. Akan tetapi, tuturan tersebut ditanggapi Yukari dengan tuturan え!? お金あるの!? じやあちょーだい！(e !? okane aru no !? jyaa cho-dai !) "Hah !? Kamu punya uang !? Sini kasih aku !". Sumbangan informasi yang diberikan Yukari bukan lah sumbangan informasi yang dibutuhkan oleh Nyamo. Hal ini terjadi karena tuturan Yukari tidak memiliki keterkaitan dengan tuturan Nyamo sebelumnya. Tanggapan yang selayaknya diberikan oleh Yukari adalah opininya mengenai keinginan Nyamo untuk membeli mobil, seperti komentar persetujuan terhadap keputusan Nyamo, perasaan ikut senang ketika melihat teman bahagia, dan lain-lain. Akan tetapi tuturan tersebut ditanggapi dengan tuturan yang berupa pengungkapan rasa irinya terhadap Nyamo karena ia memiliki uang yang banyak. Yukari berbalik meminta Nyamo untuk memberikan uang tersebut kepadanya. Hal ini didukung dengan sifat dari tokoh Yukari sendiri yaitu selalu iri dan tidak mau kalah dengan orang lain. Ia selalu merasa kesal jika orang-orang di sekitarnya mendapatkan kesenangan. Dalam pelanggaran prinsip kerja sama ini, tuturan Yukari melanggar Maksim Relevansi, karena di dalam Maksim Relevansi setiap peserta tutur diharuskan 
untuk memberikan kontribusi yang relevan dengan topik pembicaraan. Sedangkan sumbangan informasi Yukari tidak relevan dengan topik yang sedang dibicarakan.

\section{Humor Dalam Bentuk Asertif}

\subsection{Humor Asertif "Menyatakan"}

Di bawah ini adalah gambar dialog yang tuturan tokohnya masuk dalam kategori ilokusi asertif "menyatakan". Dialog ini terdapat pada manga Azumanga Daioh Volume 1 halaman 24.

\section{Gambar 2.1}

Dialog 2 (ガキのくせに)

ガキのくせに
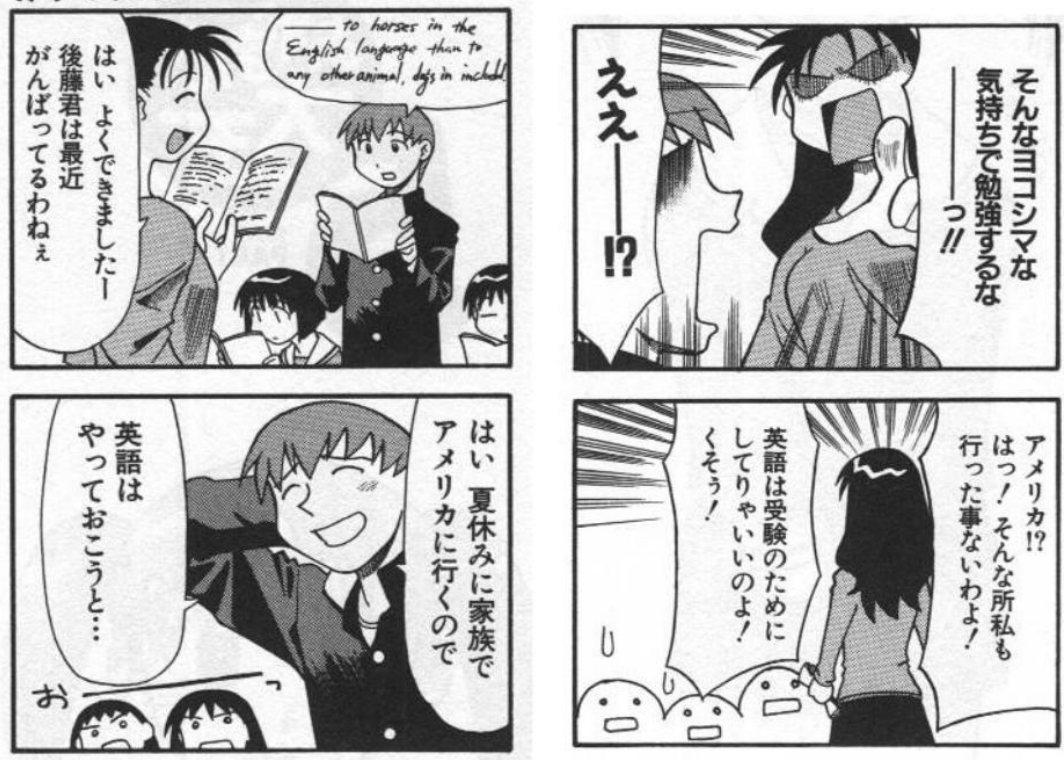

\section{Konteks Dialog 2}

Partisipan dalam dialog 2 terjadi antara Tanizaki Yukari dan Goto Masao. Percakapan tersebut terjadi di kelas 1-3 ketika Yukari sedang mengajar siswanya bahasa Inggris. Yukari merupakan guru bahasa Inggris sekaligus wali guru dari kelas 1-3. Di dalam percakapan tersebut, Yukari memberikan tugas kepada Masao untuk membaca kalimat bahasa Inggris yang terdapat di dalam buku teks. Masao membaca kalimat tersebut dengan fasih dan lancar. Setelah Masao selesai membaca, Yukari memberikan pujian kepada Masao. Masao pun menanggapi dengan mengatakan bahwa ia akan pergi berlibur ke Amerika bersama keluarga dan ingin berbicara dalam 
Febryan Ariefandi, Ilokusi yang Memberikan Efek Humor kepada Pembaca dalam Manga Azumanga Daioh

bahasa Inggris dengan lancar. Mendengar jawaban tersebut Yukari tiba-tiba marah kepada Masao tanpa alasan yang jelas.

\section{Analisis}

Tindak tutur ilokusi yang terdapat pada dialog 2 adalah asertif "menyatakan". Hal ini dapat dibuktikan pada tuturan nomor 4, yaitu アメリカ！？はっ！そんな所 私も行った事ないわよ! 英語は受験のためにしてりやいいのよ! くそ! (Amerika !? Hah! Sonna tokoro watashi mo itta koto nai wa yo ! Eiga ha jyuken no tame ni shiterya ii no yo! Kuso!) yang berarti “Amerika !? Bah! Aku juga belum pernah pergi ke tempat seperti itu ! Belajar bahasa Inggris itu untuk ujian masuk universitas! Dasar !”. Pada tuturan アメリカ！？はっ！そんな所私も行った事な いわよ! Yukari menyampaikan informasi sebenar-benarrnya bahwa ia belum pernah sekalipun pergi ke Amerika.

Di dalam tuturan dialog 2 nomor 4 Yukari mengatakan bahwa ia belum pernah pergi ke Amerika. Makna ilokusi dari tuturan tersebut adalah Yukari merasa iri dengan Goto karena ia memiliki kesempatan untuk berlibur ke Amerika dengan orang tuanya selama liburan musim panas, sedangkan dirinya yang sudah dewasa belum pernah sekalipun pergi kesana. Yukari meluapkan perasaan irinya kepada Goto dengan memarahinya. Hal ini dapat dibuktikan pada tuturan 英語は受験のためにし てりやいいのよ! くそ! . Pada akhir tuturan ia menggunakan kata くそ yang secara harafiah berarti "kotoran" (pada tuturan ini diartikan sebagai "dasar"), sebuah kata yang sering digunakan untuk mengumpat atau meluapkan perasaan marah atau kesal oleh orang Jepang. Sebagai seorang guru, Yukari dituntut untuk bersifat bijaksana dan tidak gegabah dalam melakukan suatu tindakan. Akan tetapi, Yukari tidak mencerminkan sifat seorang guru sama sekali. Emosinya mudah terpancing hanya karena salah seorang muridnya memiliki kesempatan pergi ke Amerika ketika liburan musim panas. Hal ini didukung dengan sifatnya yang selalu iri atas kebahagiaan orang lain dan mudah marah. Dalam sebuah percakapan, tuturan Yukari yang terdapat pada dialog 5 nomor 4 dapat dikategorikan sebagai tuturan yang tidak wajar karena ia seenaknya sendiri memarahi muridnya dengan alasan sepele dan cenderung tidak masuk akal. Tuturan tidak wajar inilah yang menimbulkan efek humor. Apabila mangaka selaku penutur dalam manga ini membuat tuturan Yukari 
menjadi tuturan yang wajar, misalnya “そうですか。楽しそうですね。“ maka tuturan Yukari akan terasa datar dan tidak menimbulkan efek lucu bagi pembaca selaku mitra tutur.

Selain itu, dilihat dari sudut pandang Prinsip Kerja Sama, tuturan Yukari pada dialog 2 nomor 4 tidak melanggar Maksim Kualitas. Yukari mengatakan hal sebenarnya bahwa ia belum pernah sekalipun pergi ke Amerika. Selain itu, tuturannya juga tidak melanggar Maksim Relevansi karena apa yang ia tuturkan memiliki hubungan dengan tuturan yang telah dituturkan oleh Goto. Akan tetapi, tuturan Yukari telah melanggar Maksim Kuantitas dan Maksim Cara pada Prinsip Kerja Sama. Hal ini dapat dibuktikan pada tuturan アメリカ！？はっ！そんな所私も行った 事な いわよ!英語は受験のためにしてりやいいのよ！〈そ!(Amerika !? Hah！ Sonna tokoro watashi mo itta koto nai wa yo !Eiga ha jyuken no tame ni shiterya ii no yo! Kuso ! ) yang berarti “Amerika !? Bah ! Aku juga belum pernah pergi ke tempat seperti itu ! Belajar bahasa Inggris itu untuk ujian masuk kuliah! Dasar !”. Pada tuturan tersebut Yukari memberikan sumbangan informasi yang berlebihan pada Goto. Goto menceritakan rencananya untuk berlibur ke Amerika bersama keluarganya di musim panas. Sumbangan informasi yang seharusnya diberikan oleh Yukari adalah tanggapan singkatnya mengenai rencana Goto tersebut, seperti そうか。楽しそう ね。(sou ka. Tanoshisou ne.) yang berarti “oh begitu. Sepertinya menyenangkan ya.”. Akan tetapi Yukari menanggapinya dengan mengatakan bahwa ia belum pernah sekalipun pergi ke Amerika dan seharusnya belajar bahasa inggris hanya digunakan untuk ujian masuk universitas. Ia mengatakan hal tersebut dengan marah-marah, terbukti dengan digunakannya kata くそ yang secara harafiah berarti "kotoran", sebuah kata yang sering digunakan untuk mengumpat oleh orang Jepang. Sumbangan informasi yang ia berikan terlalu banyak, sehingga melanggar maksim kuantitas pada prinsip kerja sama.

Tuturan dialog 2 nomor 4 juga melanggar Maksim Cara. Hal ini dapat dibuktikan pada tuturan tuturan アメリカ！？はっ！そんな所私も行った事ない わよ! 英語は受験のためにしてりやいいのよ! くそ! (Amerika !? Hah! Sonna tokoro watashi mo itta koto nai wa yo ! Eiga ha jyuken no tame ni shiterya ii no yo! Kuso ! ) yang berarti "Amerika !? Bah ! Aku juga belum pernah pergi ke tempat 
Febryan Ariefandi, Ilokusi yang Memberikan Efek Humor kepada Pembaca dalam Manga Azumanga Daioh

seperti itu ! Belajar bahasa Inggris itu untuk ujian masuk kuliah! Dasar !”. Pada tuturan tersebut Yukari menanggapi tuturan Goto dengan marah-marah sambil mengatakan bahwa ia belum pernah sekalipun pergi ke Amerika. Ia juga menasihati agar Goto belajar bahasa Inggris bukan untuk bersenang-senang, tetapi untuk ujian masuk universitas. Tuturan Yukari tersebut tidak jelas dan berbelit-belit. Walaupun sumbangan informasi yang diberikan Yukari memiliki korelasi dengan topik tuturan Goto sebelumnya, tetapi tuturan Yukari yang mengatakan bahwa ia belum pernah pergi ke Amerika dan belajar bahasa Inggris hanya digunakan untuk ujian masuk universitas kurang tepat digunakan untuk menanggapi tuturan Goto tersebut. Seharusnya, sebagai seorang guru Yukari dituntut untuk bersikap lebih bijaksana dan tidak meluapkan emosinya kepada siswanya. Misal, ia dapat menanggapi tuturan Goto dengan mengatakan bahwa ia ikut senang atas rencana Goto untuk berlibur di Amerika bersama keluarga. Akan tetapi, ia justru meluapkan emosinya dengan mengatakan bahwa ia belum pernah pergi ke Amerika dan belajar bahasa Inggris hanya digunakan untuk ujian masuk universitas saja. Oleh karena itu, tuturan Yukari yang berbelit-belit tersebut masuk dalam kategori pelanggaran maksim cara pada Prinsip Kerja Sama.

\section{Humor Dalam Bentuk Ekspresif}

\subsection{Humor Ekspresif "Mengkritik"}

Di bawah ini adalah gambar dialog yang tuturan tokohnya masuk dalam kategori ilokusi ekspresif "mengkritik". Dialog ini terdapat pada manga Azumanga Daioh Volume 1 halaman 119. 
Gambar 3.1

Dialog 3 (ぶっちぎり)

ぶつちキり
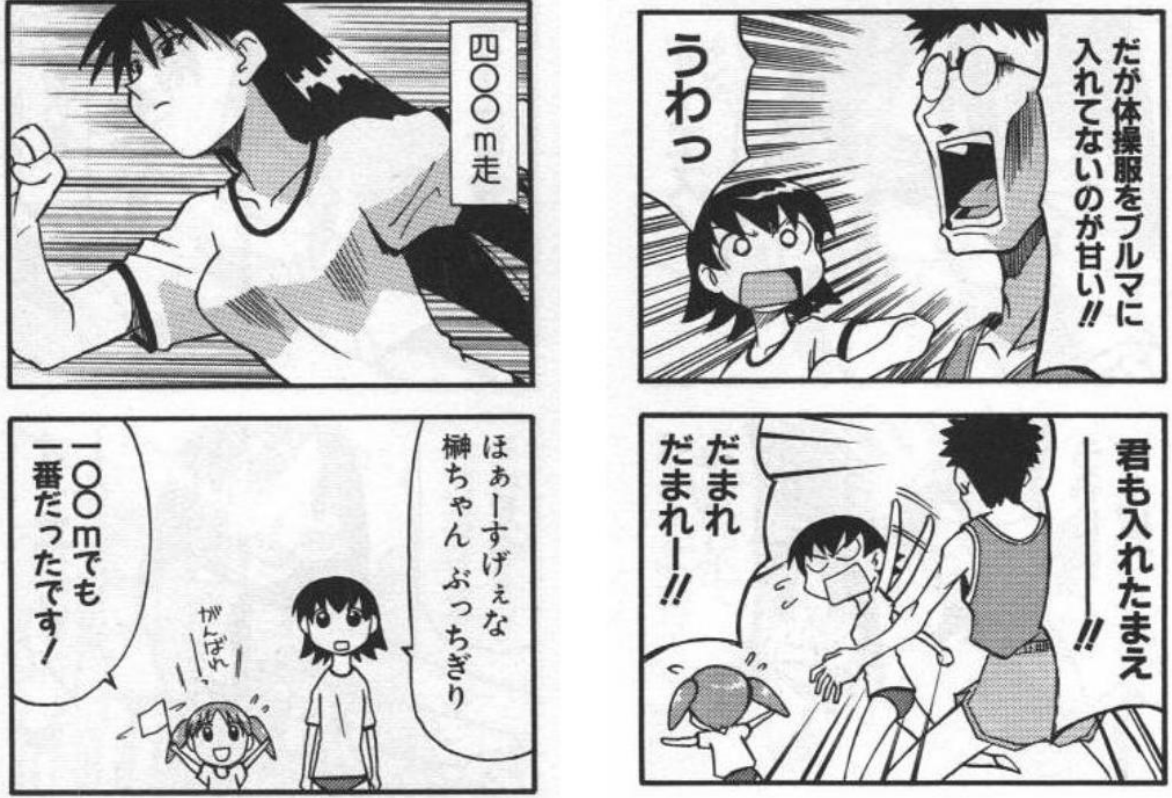

\section{Konteks Dialog 3}

Dialog 3 terjadi di lapangan olahraga ketika kegiatan festival olahraga sekolah sedang berlangsung. Partisipan dalam dialog ini adalah Ryuunou Tomo, Mihama Chiyo, dan Kimura Sensei. Tomo bercerita kepada Chiyo mengenai kehebatan Sakaki (teman sekelas mereka) dalam berolahraga lari. Chiyo pun menanggapi dengan mengatakan bahwa ketika lari di rute 100 meter pun Sakaki tetap menjadi nomor 1. Tiba-tiba tanpa diketahui kedatangannya, Pak Kimura menanggapi pembicaraan mereka dengan mengatakan bahwa siswi yang tidak memasukkan seragam olahraganya ke dalam celana olahraga adalah siswi yang manja. Setelah itu ia pun menyuruh Tomo dan Chiyo untuk memasukkan seragam olahraganya ke dalam celana. Mendengar tuturan tersebut Tomo dan Chiyo pun kaget dan berlari meninggalkan Kimura sensei.

\section{Analisis}

Tindak tutur ilokusi yang terdapat pada dialog 3 nomor 3 adalah Ekspresif "mengkritik". Tuturan Pak Kimura sebagai penutur dimaksudkan untuk mmengkritik Tomo selaku mitra tutur agar ujarannya diartikan sebagai evaluasi tentang hal yang disebutkan di dalam tuturan itu. Hal ini dapat dibuktikan pada tuturan dialog 3 nomor 
Febryan Ariefandi, Ilokusi yang Memberikan Efek Humor kepada Pembaca dalam Manga Azumanga Daioh

3 yaitu だが体操服をブルマーに入れてないのが甘い！！(Daga taishoufuku wo buruma ni iretenai no ga amai!!.) yang berarti "Tapi dia bodoh karena tidak memasukkan seragam senam ke dalam celananya". Tuturan Pak Kimura tersebut adalah tuturan untuk mengkritik perbuatan Sakaki chan yang tidak memasukkan seragam senam ke dalam celananya. Di dalam tuturan tersebut ia menggunakan kata “甘い” yang berarti naïf atau dapat pula diartikan sebagai bodoh ketika sedang mengkritik orang. Oleh karena itu tuturan Pak Kimura tuturan tersebut digunakan untuk mengkritik perbuatan seseorang, maka tuturan Pak Kimura tersebut masuk dalam tuturan tindak tutur ekspresif "mengkritik".

Di dalam tuturan dialog 3 nomor 3 Pak Kimura mengatakan bahwa Sakaki bodoh karena tidak memasukkan baju senamnya ke dalam celana. Makna ilokusi dari tuturan tersebut adalah sebenarnya Pak Kimura ingin melihat siswinya menggunakan seragam senam dengan memasukan bajunya ke dalam celana. Pak Kimura terkenal sebagai guru yang mesum, yang sering mengganggu aktifitas siswinya baik melalui perbuatan maupun perkataannya. Di sini ia ingin melampiaskan hasratnya untuk melihat para siswinya menggunakan seragam sesuai dengan keinginannya. Sebagai seorang guru, tindak tanduknya harus bisa dijadikan contoh oleh siswanya. Akan tetapi ia memberikan contoh yang tidak bagus dengan mengatakan hal yang seharusnya tidak dikatakan oleh seorang guru.

Dalam sebuah percakapan, tuturan Pak Kimura yang terdapat pada dialog 3 nomor 3 dapat dikategorikan sebagai tuturan yang tidak wajar karena tergolong sebagai tuturan yang mesum dan tidak bermoral. Pak Kimura muncul secara tiba-tiba dengan mengatakan sesuatu yang tidak pantas dikatakan oleh seorang guru dan tidak ada hubungannya dengan topik yang sedang di perbincangkan oleh Tomo dan Chiyo. Tuturan tidak wajar inilah yang menimbulkan efek humor. Apabila mangaka selaku penutur dalam manga ini membuat tuturan Pak Kimura menjadi tuturan yang wajar, misalnya ia menanggapi tuturan Tomo dan Chiyo dengan mengatakan “そうですね。 榊さんはスポーツが上手ですね。”maka tuturan Pak Kimura akan terasa biasabiasa saja dan tidak menimbulkan efek lucu bagi pembaca selaku mitra tutur.

Selain itu, tuturan Pak Kimura pada dialog 3 nomor 3 juga telah melanggar Maksim Relevansi pada Prinsip Kerja Sama. Hal ini dapat dibuktikan pada tuturan だ 
が体操服をブルマーに入れてないのが甘い！ ! (Daga taishoufuku wo buruma ni iretenai no ga amai!!.) yang berarti "Tapi dia bodoh karena tidak memasukkan seragam senam ke dalam celananya". Pada tuturan tersebut ia tiba-tiba mengkritik Sakaki chan yang tidak memasukkan baju senamnya ke dalam celana. Tuturannya tidak memiliki korelasi dengan topik tuturan yang diujarkan oleh Tomo dan Chiyo. Pada saat itu mereka sedang memuji kehebatan Sakaki dalam olahraga lari. Pada tuturan dialog 3 nomor 1 Tomo mengatakan ほあ一一すげえなあ。榊ちゃんぶっ ちぎり(Hoa-sugee naa. Sakaki chan bucchigiri) yang artinya "Wah.. hebat ya. Sakaki menang telak". Ia memuji kehebatan Sakaki yang dapat menang telak dari lawan dengan mudahnya. Setelah itu pada tuturan dialog 3 nomor 2 Chiyo pun menanggapi dengan —oomでも一番だったです。(hyaku meteru demo ichiban datta desu.) yang berarti "di rute 100 meter pun ia nomer satu”. Ia menyatakan bahwa di rute 100 meter pun Sakaki mendapatkan peringkat satu. Akan tetapi Pak Kimura tiba-tiba menanggapi pembicaraan mereka dengan mengatakan bahwa Sakaki bodoh karena tidak memasukkan baju senamnya ke dalam celana. Karena tidak memiliki hubungan dengan topi $\mathrm{k}$ yang sedang di bicarakan sebelumnya, maka tuturannya tersebut melanggar Maksim Relevansi pada Prinsip Kerja Sama.

\section{Humor Dalam Bentuk Komisif}

\subsection{Humor Komisif "Menawarkan"}

Di bawah ini adalah gambar dialog yang tuturan tokohnya masuk dalam kategori ilokusi komisif "menawarkan". Dialog ini terdapat pada manga Azumanga Daioh Volume 1 halaman 116. 
Febryan Ariefandi, Ilokusi yang Memberikan Efek Humor kepada Pembaca dalam Manga Azumanga Daioh

Gambar 4.1

Dialog 4 (おいしいよ)
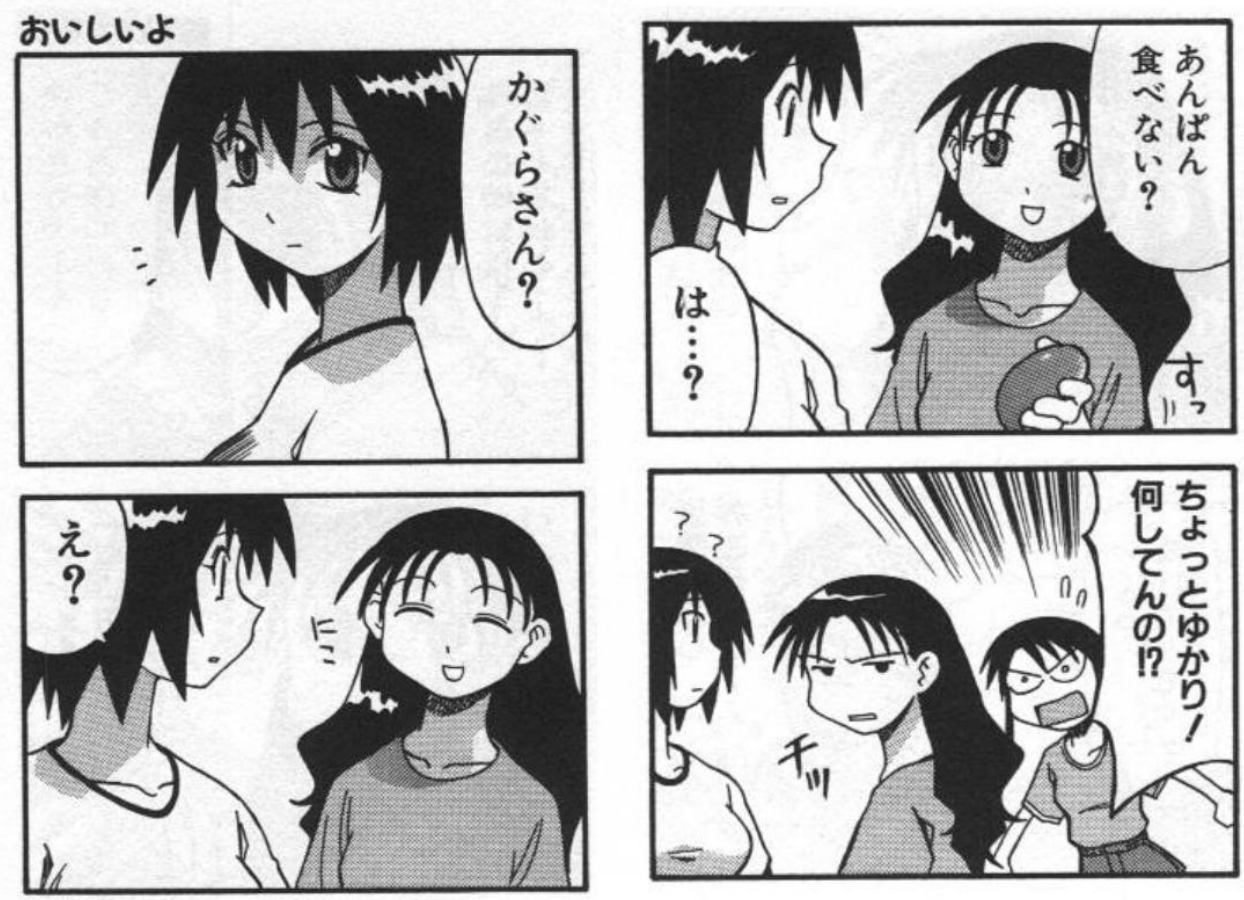

\section{Konteks Dialog 4}

Dialog 4 terjadi di lapangan olahraga ketika kegiatan festival olahraga sekolah sedang berlangsung. Partisipan dalam dialog ini adalah Tanizaki Yukari, Kagura, dan Kurosawa Minamo. Ketika kegiatan olahraga sedang berlangsung, Yukari menghampiri Kagura sambil menawarkan apakah Kagura ingin memakan sebuah roti. Nyamo yang melihat kejadian ini langsung menghentikan aksi Yukari yang mencurigakan tersebut.

Tindak Tutur Ilokusi yang terdapat pada dialog 4 adalah Komisif “menawarkan”. Hal ini dapat dibuktikan pada tuturan nomor 3, yaitu アンパン食べな W? (anpan tabenai?) yang berarti “kamu mau makan roti?”. Yukari menghampiri Kagura dan menawarkan apakah ia ingin makan roti. Oleh karena itu tuturan tersebut masuk dalam kategori Tindak Tutur Ilokusi Komisif “menawarkan”. 
Di dalam tuturan dialog 4 nomor 3 Yukari menghampiri Kagura dan mengatakan mengatakan アンパン食ベない? (anpan tabenai?) yang berarti “kamu mau makan roti?". Ia menawarkan apakah Kagura ingin makan roti atau tidak. Makna Ilokusi dari tuturan tersebut adalah sebenarnya Yukari ingin memberikan roti yang sudah tidak layak makan agar Kagura sakit perut dan tidak dapat bertanding di festival olahraga sekolah mereka. Yukari terkenal sebagai guru yang curang dan licik. Ketika ia mengetahui bahwa didalam pertandingan lari kelasnya ( kelas 1-3) akan bertanding dengan kelas Nyamo (1-

5) yang merupakan sahabat dekatnya, ia memiliki ide untuk berbuat curang. Ia ingin memberikan kue yang sudah tidak layak makan kepada Kagura agar sakit perut dan tidak dapat bertanding di pertandingan lari. Kagura adalah siswa yang terkenal dengan kemampuannya dalam olahraga, khususnya olahraga lari. Oleh karena itu ia ingin menjatuhkan Kagura agar kelasnya tidak memiliki lawan yang tangguh dan berhasil menang dengan mudah. Akan tetapi, aksinya tersebut diketahui oleh Nyamo. Hal ini

terdapat pada tuturan 5 yaitu ちょっとゆかり!何してんの！?(chotto Yukari! Nani shiten no?) yang berarti “Tunggu, Yukari! Apa yang kamu lakukan?”. Nyamo yang mengetahui sifat buruk sahabatnya itu berusaha untuk mencegah aksi Yukari agar ia gagal memberikan roti tersebut kepada Kagura.

Dalam sebuah percakapan, tuturan Yukari yang terdapat pada dialog 4 nomor 3 mungkin dapat dikategorikan sebagai tuturan yang wajar karena ia sebagai penutur menawarkan sebuah roti kepada Kagura selaku mitra tutur. Akan tetapi jika dilihat pada konteksnya, tuturan Yukari menjadi tindak wajar karena maksud dari tuturannya tersebut adalah ia ingin menjatuhkan Kagura agar sakit perut setelah memakan roti tersebut. Sifat licik yang tidak secara langsung tersirat dalam tuturan tersebut membuat tuturannya menjadi lucu. Hal ini didukung dengan sifat Yukari yang licik dan curang dan tuturan Nyamo yang berusaha mencegah aksi tersebut karena ia mengetahui apa yang sebenarnya dipikirkan oleh Yukari. Tuturan Yukari inilah yang menimbulkan efek Humor. Mangaka selaku penutur dalam humor ini berusaha mengajak pembaca selaku mitra tutur untuk menangkap makna tersirat di dalam tuturan Yukari tersebut yang mengandung efek humor. 
Febryan Ariefandi, Ilokusi yang Memberikan Efek Humor kepada Pembaca dalam Manga Azumanga Daioh

Selain itu, tuturan Yukari pada dialog 4 nomor 3 juga telah melanggar Maksim Kualitas pada Prinsip Kerja Sama. Hal ini dapat dibuktikan pada tuturan アンパン食 ベな

い? (anpan tabenai?) yang berarti "kamu mau makan roti?". Pada tuturan tersebut Yukari berusaha menawarkan roti kepada Kagura, seolah-olah roti tersebut adalah roti biasa yang layak di makan. Padahal sebenarnya roti yang akan diberikan adalah roti yang kadaluarsa atau tidak layak makan. Ia berusaha menutup-nutupi kenyataan tersebut

agar Kagura mau memakan roti pemberiannya, dan rencananya untuk membuat Kagura sakit perut berhasil. Karena Yukari menutup-nutupi kebenaran tentang roti tersebut dengan memberikan sumbangan informasi yang tidak sesuai fakta, maka tuturan Yukari dapat dikategorikan sebagai pelanggaran Maksim Kualitas pada Prinsip Kerja Sama.

\section{Humor Dalam Bentuk Deklaratif}

\subsection{Humor Deklaratif "Memutuskan"}

Di bawah ini adalah gambar dialog yang tuturan tokohnya masuk dalam kategori ilokusi deklaratif "memutuskan”. Dialog ini terdapat pada manga Azumanga Daioh Volume 1 halaman 48.

\section{Gambar 5.1}

Dialog 5 (大阪)
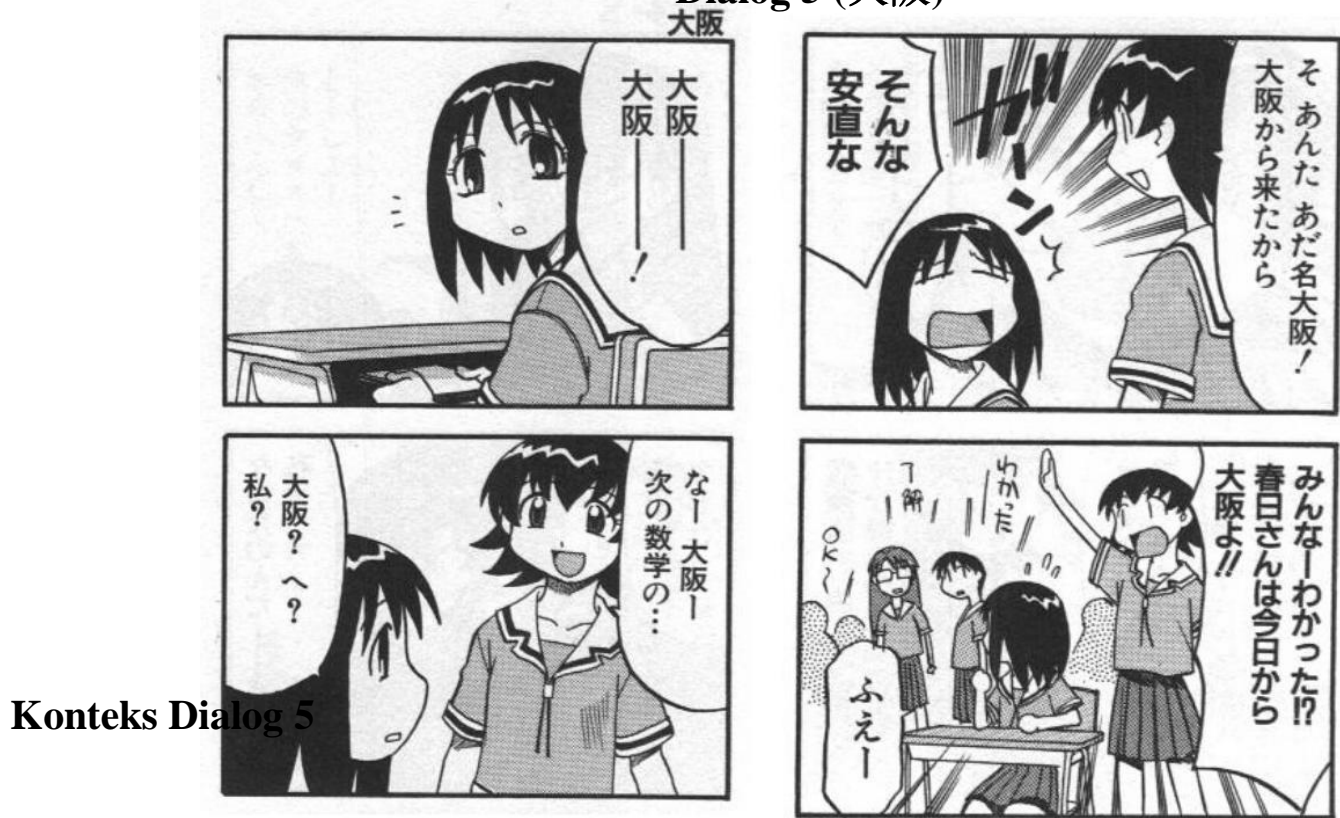
Dialog 5 terjadi di kelas 1-3 ketika jam istirahat. Partisipan dalam dialog ini adalah Ryuuno Tomo dan Kasuga Ayumu. Tomo menghampiri Kasuga untuk menanyakan tentang pelajaran selanjutnya. Karena Kasuga berasal dari Oosaka, Tomo memanggilnya dengan sebutan Oosaka. Kasuga yang kebingungan menanyakan kepada Tomo apakah yang dimaksud dengan Oosaka adalah dirinya. Tomo pun mengiyakan tuturan Kasuga dengan alasan ia berasal dari Oosaka. Kasuga yang kaget mengatakan bahwa mengapa Tomo memutuskan nama panggilannya dengan alasan semudah itu. Namun Tomo tidak menghiraukan pernyataan Kasuga dan seenaknya sendiri memutuskan bahwa mulai hari itu nama panggilan Kasuga adalah Osaka.

Tindak Tutur Ilokusi yang terdapat pada dialog 5 adalah Deklaratif "memutuskan". Tuturan Tomo selaku penutur adalah tindak tutur yang dimaksudkan penuturnya untuk menciptakan hal (status, keadaan, dan sebagainya) yang baru dengan memutuskan sesuatu. Hal ini dapat dibuktikan pada tuturan nomor 5, yaitu みんな一 わかった！？春日さんは今日から大阪よ！(Minna-wakatta!？ Kasuga san ha kyou kara oosaka yo!) yang berarti "teman-teman- kalian paham!? Mulai hari ini Kasuga dipanggil Osaka! “. Pada tuturan 今日から大阪 Tomo dengan seenaknya memutuskan bahwa mulai pada hari itu nama panggilan Kasuga adalah Oosaka. Hal itu didasari karena ia berasal dari Oosaka. Tuturan Tomo yang memutuskan suatu hal dengan seenaknya sendiri tersebut masuk dalam kategori tindak tutur ilokusi deklaratif "memutuskan".

Di dalam tuturan dialog 5 nomor 5 Tomo memutuskan bahwa mulai hari itu nama panggilan Kasuga adalah Oosaka. Makna ilokusi dari tuturan tersebut adalah sebenarnya Tomo ingin mempermalukan Kasuga di depan teman-temannya dengan memberikan nama panggilan yang aneh, yaitu “Oosaka”. Pada tuturan あだ名大阪。 大阪から来たから yang terdapat pada dialog 5 nomor 3 Tomo memberikan nama panggilan tersebut dengan alasan bahwa Kasuga berasal dari Oosaka. Padahal sebenarnya ia hanya merasa iri kepada Kasuga dan bermaksud untuk menjelekjelekannya. Tomo merasa bahwa Kasuga adalah saingannya karena menurutnya orang yang berasal dari Oosaka memiliki bakat melawak yang bagus. Menurut pendapatnya, sebagai siswi yang paling aktif dan memiliki selera humor yang tinggi, Tomo merasa tersaingi dengan kedatangan Kasuga di sekolahnya. 
Febryan Ariefandi, Ilokusi yang Memberikan Efek Humor kepada Pembaca dalam Manga Azumanga Daioh

Dalam sebuah percakapan, tuturan Tomo yang terdapat pada dialog 5 nomor 5 adalah tuturan yang tidak wajar. Ia seenaknya sendiri memberikan nama panggilan kepada seseorang yang belum tentu orang tersebut mau menerimanya. Hal tersebut didukung dengan tuturan Kasuga pada dialog 5 nomor 5 yaitu そんな安直な (sonna anchoku na) yang berarti "segampang itu kah..". Dari tuturan tersebut dapat disimpulkan bahwa ia merasa keberatan dengan nama panggilan pemberian Tomo. Akan tetapi, bukannya meminta maaf, Tomo dengan sengaja mendeklarasikan di depan teman-teman kelasnya bahwa mulai hari itu nama panggilan Kasuga adalah Oosaka. Tuturan Tomo yang tidak terduga inilah yang memberikan efek humor. Jika mangaka selaku penutur membuat tuturan Tomo menjadi tuturan yang biasa saja, misal Tomo meminta maaf kepada Kasuga karena telah memberikan nama panggilan seenaknya, tentu saja tuturan tersebut akan terasa datar dan tidak menimbulkan efek humor bagi pembaca selaku mitra tutur.

Selain itu, tuturan Tomo pada dialog 5 nomor 5 juga telah melanggar Maksim Relevansi pada prinsip kerja sama. Hal ini dapat dibuktikan pada tuturan yaitu みんな 一わかった！？春日さんは今日から大阪よ！(Minna-wakatta!？Kasuga san ha kyou kara oosaka yo!) yang berarti "teman-teman, kalian paham!? Mulai hari ini Kasuga dipanggil Osaka! “. Pada tuturan sebelumnya yaitu dialog 5 nomor 4 そんな 安直な (sonna anchoku na) yang berarti “segampang itu kah..”, Kasuga menyatakan keberatannya atas nama panggilan yang Tomo berikan. Ia mengeluhkan keputusan Tomo yang memberikan nama panggilan "Oosaka" hanya karena ia berasal dari Oosaka. Akan tetapi, Tomo tidak menghiraukan pernyataan Kasuga tersebut dan mengumumkan kepada teman-temannya bahwa mulai hari itu nama panggilan Kasuga adalah Oosaka. Tuturan Tomo tidak memiliki korelasi dengan tuturan Kasuga sebelumnya yaitu ketika ia mempermasalahkan cara Tomo memberikan nama panggilan kepadanya. Oleh karena itu tuturan tersebut dapat dikategorikan sebagai pelanggaran Maksim relevansi pada Prinsip Kerja Sama.

\section{SIMPULAN}

Berdasarkan hasil penelitian yang telah dilakukan oleh penulis mengenai analisis Tindak Tutur Ilokusi yang menunjang terjadinya efek humor pada tuturan tokoh dalam 
manga Azumanga Daioh volume 1, ditemukan lima macam Tindak Tutur Ilokusi. Tindak Tutur Ilokusi tersebut antara lain Ilokusi Asertif berjumlah lima, Ilokusi Direktif berjumlah empat, Ilokusi Ekspresif berjumlah Dua, dan Ilokusi Komisif dan Deklaratif yang masing-masing berjumlah satu. Daya ilokusi yang terdapat pada tuturan-tuturan para tokoh dalam manga Azumanga Daioh Volume 1 antara lain Asertif "mengakui", "menyatakan", dan "berspekulasi”, Direktif "memerintah" dan "melarang", Ekspresif "mengkritik", Komisif "menawarkan", dan Deklaratif “memutuskan". Tuturan Ilokusi para tokoh juga cenderung tidak wajar dan memiliki makna Ilokusi diluar ekspektasi.

Selain itu, tuturan Ilokusi para tokoh juga telah melanggar maksim pada Prinsip Kerja Sama karena humor sendiri juga dapat terjadi akibat pelanggaran dalam Prinsip Kerja Sama. Maksim yang telah dilanggar dalam tuturan tersebut antara lain Maksim Kualitas, Maksim Kuantitas, Maksim Relevansi, dan Maksim Cara.

\section{REFERENSI}

Austin, J. L. (1962). How To Do Things With Words. Oxford: Oxford University Press.

Chaer, A., \& Agustina, L. (2004). Sosiolinguistik Perkenalan Awal. Jakarta: PT. Rineka Cipta.

Claire, E. (1984). What's so Funny. Rochele Park: Endley Pub.

Ellytias, R. D. (2013). Pelanggaran Prinsip Kerja Sama Sebagai Penunjang

Pengungkapan Manga Kureyon Shinchan Volume 10. Semarang: Skripsi Universitas Dian Nuswantoro.

Ensiklopedi Indonesia. (1982). Jakarta: Ikhtisar Baru-Van Hoeve.

Grice, H. P. (1975). Logic and Conversation. Dalam Peter Cole dan Jerry L. Morgan. $(E D S)$.

Syntax and Semantics Volume 3: Speech Acts. New York: Academic Press.

Hymes, D. (1972). Models of The Interaction of Language and Social Life. In J.

Gumperz \& D. Hymes (Eds.), Directions in Sociolinguistics: The Ethnography of Communication. New York: Holt, Rinehart, Winston.

Ibrahim, S. (1993). Kajian Tindak Tutur. Surabaya: Usaha Nasional. 
Febryan Ariefandi, Ilokusi yang Memberikan Efek Humor kepada Pembaca dalam Manga Azumanga Daioh

Kimie, O. (2013). An Examination for Styles of Japanese Humor: Japan's Funniest Story Project 2010 to 2011. Japan: Journal Bunkyo Gakuin University.

Kridalaksana, H. (2008). Kamus Linguistik. Jakarta: PT. Gramedia Pustaka Utama.

Leech, G. (1993). Prinsip-Prinsip Pragmatik. (Terj) M. D. D. Oka. Jakarta: Universitas Indonesia.

Matsura, K. (1994). Kamus Bahasa Jepang - Indonesia. Kyoto, Jepang: Kyoto Sangyo University Press.

Nadar, F. X. (2009). Pragmatik dan Penelitian Pragmatik. Yogyakarta: Graha Ilmu.

Nawa, A. (2013). Differences of Sense of Humor Between Cultures; An Analysis of Two Comedy Acts in Japan and the US. Aichi, Jepang: Thesis Aichi Shukutoku University.

Rustono. (1998). Implikatur Percakapan Sebagai Penunjang Pengungkapan Humor Di Dalam Wacana Humor Verbal Lisan Berbahasa Indonesia. Jakarta: Disertasi Universitas Indonesia.

Saifudin, A. (2005). Faktor Sosial Budaya dan Kesopanan Orang Jepang dalam Pengungkapan Tindak Tutur Terima Kasih pada Skenario Drama Televisi Beautiful Life Karya Kitagawa Eriko. Tesis.Universitas Indonesia.

Setiawan, A. (1990). Teori Humor. Jakarta: Majalah Astaga, No. 3 Th. III, hal.34-35.

Sherry, H. Q. (2012). Tindak Tutur Ilokusi dalam Buku Humor Membongkar Gurita Cikeas Karya Jaim Wong Gendeng dan Implikasinya Dalam Pembelajaran Indonesia. Padang: Skripsi Universitas Negeri Padang.

Wibowo, W. (20110. Linguistik Fenomenologis Jhon Langsaw Austin "Ketika Tuturan Berarti Tindakan". Jakarta: Bidik-Phorenis Publishing.

Wijana, I. D. (1996). Dasar-Dasar Pragmatik. Yogyakarta: Andi.

Wilson, C. (1979). Jokes: From, Content, Use, and Function. New York: Academic Press.

Yule, G. (2006). Pragmatik. Yogyakarta: Pustaka Pelajar.

http://www.britannica.com/EBchecked/topic/276309/humour. diakses pada 23 September 2014.

http://kbbi.web.id/komik. diakses pada 19 September 2014. http://www.merriam-webster.com/dictionary/humor. diakses pada 23 September 2014. 